Обзорная статья/Review article

DOI: http://doi.org/10.20914/2310-1202-2016-4-148-150

\title{
Study on plant Gums and their new development in application: with focus on tragacanth, guar and arabic Gum; a short review
}

\begin{abstract}
Farnoush Hassanpour ${ }^{1}$
1 food science and technology department, Isfahan (Khorasgan) branch, Islamic azad university, Isfahan, Iran

Summary.Gums refer to a type of polysaccharides which are used to increase viscosity and create some other functional properties such as thickening agent, emulsifying agent, stabilizer, crystal inhibitor and so forth. They are classifying based on their nature and originality including, microbial, plant, exudate and animal Gums. This article shortly reviews a group of plant Gums and recent findings in their application. Gums or Hydrocolloids are main compounds which create stability of emulsion via entering into water phase. The importance of these compounds is on viscosity and electrostatic reactions to stabilize nonalcoholic emulsion with below properties; 1) easily soluble in cold water, 2) the lowest amount of viscosity in water, 3) having maximum level of emulsifier amount, 4) no creation of gelling. Diversity and functionality of Gums and regarding their still novelty in food industries have made Gums one of the main additives in food formulations. Since sourced of Gums are different we must focus on using them together to improve their synergistic effect but interactions among them and combined matrixes produced by them also need to be studied in details.
\end{abstract}

Keywords: guar, arabic Gum, tragacanth Gum, Functional properties

\section{Introduction}

There are many challenges in way of production of functional beverages. The main target is supplying health claims and permanent developments of flavor profile and desire mouth feel throughout their shelf life.

Formulating a functional component is an obligation and fulfillment of functional properties is one of the controversial issues in production of any functional foods. All these challenges increase in terms of final product. It must be noted that compounds are final and critical items in ensuring the quality and safety of final products (Pimenov N., 2015). Before formulating, it is important that final functionality must define base on all the food ingredients (Pimenov N., 2016).

\section{stabilization}

Texture definitions and beverages

Texture is a wide term which covers many rheological and sensorial qualities. Texture covers appearance and mouth feel of beverage when drink: appearance when poring, glassing on bottle, mouth feel, precipitation of taste.

The importance of rheological behavior, in particular flow properties of hydrocolloids can be related to mouth feel and textural properties of Gum (Glykex Mann, 1982). Stabilizing, a term relating to bio-physiochemical mechanism is complicated and different. Each parameter needs to be categorized correctly and overall, a stabilized beverage is homogenous and flow. A homogenous beverage defines as a beverage with no gelling status, no viscosity, lack of layer forming, lack of phase separation, lack of clarification,

\section{Для цитирования}

Farnoush Hassanpour.Study on plant Gums and their new development in application: with focus on tragacanth, guar and arabic Gum; a short review // Вестник ВГУИТ.2016. № 4. С. 148-150. doi:10.20914/2310-1202-2016-4-148-150 with no flocculation (Pimenov N., 2013). Each parameter has different parts and depends on formulation and process of beverage.

Mainly, hydrocolloids create the following proerpties in different formulation of food stuffs:

- Viscosity enhancing or thickening properties

- Gelling properties

- Surface activity and emulsifying properties

- Hydrocolloids as edible films and coatings

- Fat replacers

Hydrocolloids can modify organoleptic properties and consider as one of food additives. Due to the property of having conformationally disorder chains, hydrocolloids are good alternatives for creating thickening agent. In regards to create thickening properties polymer solvent interaction is needed (Philips et al., 1986).

There are several factors affecting aforesaid property such as the type of used hydrocolloid, its concentration and food system.

From the viewpoint of functionality hydrocolloids categorize in two groups as follows:

1) Thickening agent: creating beverage texture but unable to make it suspension, they slow down precipitation of oil droplet with no possibility of prevention of separation.

2) Gelling agent: make connections and bond among molecules along with 3 dimensional matrixes. It leads to stabilize oil droplets in matrix and thus density of created droplets will be less than the amount of efficacy in matrix.

Since Gums have solid soft matrix, they can widely use in food applications. Some correlated phenomenon is affecting emulsifier properties of Gums

For citation

Farnoush Hassanpour.Study on plant Gums and their new development in application: with focus on tragacanth, guar and arabic Gum; a short review. Vestnik VSUET [Proceedings of VSUET]. 2016. no. 4.pp. 148-150. (in Russian). doi:10.20914/2310-1202-2016-4-148-150 


\section{Becmник BTYYHST/Proceedings of VSUET, № 4, 2016}

which include retarding of precipitation, diminishing of oil droplet and so forth. It must be noted that Gums will adsorb very slowly onto liquid surface.

Gums or Hydrocolloids are main compounds which create stability of emulsion via entering into water phase. The importance of these compounds is on viscosity and electrostatic reactions to stabilize nonalcoholic emulsion with below properties; 1) easily soluble in cold water, 2) the lowest amount of viscosity in water, 3) having maximum level of emulsifier amount, 4) no creation of gelling.

\section{Introduce of some Gums}

\subsection{Guar}

Guar Gum and Locust Bean Gum: they are galactomanam extracted from endosperm of $\mathrm{Cy}$ amopsistertragonobola and Ceratoniasiliqua respectively. Endosperm parts degrade to fine particles. Both Gums compose of glycoside bonds $(\beta 1,4)$ and a bond on branch which connects Galactose.

\subsection{Arabic Gum}

Acacia Gum or so-called Arabic Gum is used since thousand years ago is an exudate Gum and today known as an additive (Imenson, 2010). The structure of Gum Arabic is relatively complex. The main chain of this polysaccharide is built from $(1 \rightarrow 3)$ and $(1 \rightarrow 6)$ linked $\beta$-D-galactopyranosyl.

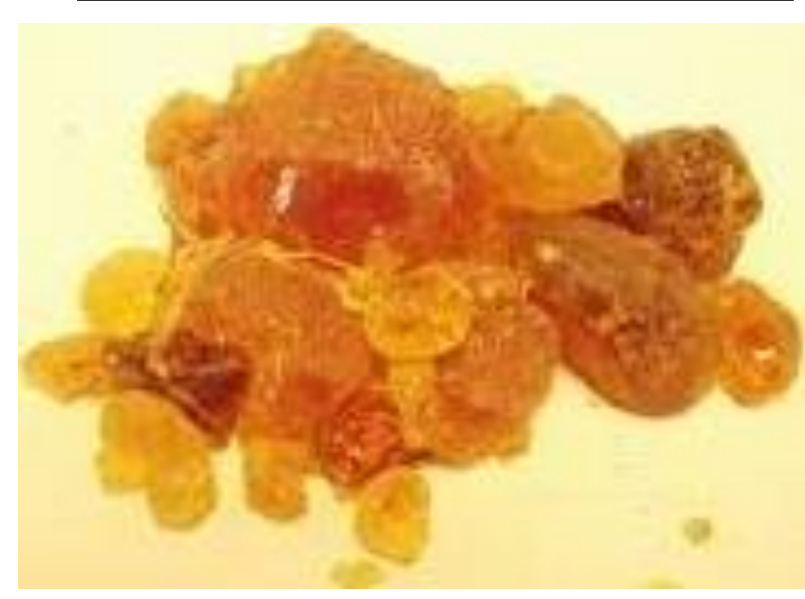

Figure 1. Arabic Gum

\subsection{Tragacanth Gum}

This kind of Gum exudate from Astragalus Gummifer Labillardiere and other special species of Astragalus from western Asia (mostly in Iran, some in Turkey). This type includes a water soluble part which is contained $30-40 \%$ of Gum Structure which is a highly branched neutral polysaccharide composed of $1 \rightarrow 6$-linked D-galactosyl backbones with L-arabinose side chains joined by $1 \rightarrow 2,1 \rightarrow 3-$ and/or $1 \rightarrow 5$-linkages.

Table 1.

Summary of the recent finding on Arabic, Guar and Tragacanth Gums

\begin{tabular}{|c|c|c|}
\hline Reference & The type of Gum studied & Results \\
\hline Hu et al, 2016 & $\begin{array}{l}\text { Gum Arabic purpose of present work } \\
\text { was to develop eugenol oil nanoemul- } \\
\text { sions using Gumarabic and lecithin as } \\
\text { food grade natural emulsifiers, and } \\
\text { study their antimicrobial activity. }\end{array}$ & $\begin{array}{l}\text { Results showed that nanoemusions with aparticle } \\
\text { size of } 103.6 \pm 7.5 \mathrm{~nm} \text { were obtained by mixing } \\
\text { aqueous phase }(0.5 \% \text { Gum arabic, } 0.5 \% \text { lecithin, } \\
\text { w/v) and eugenol oil ( } 1.25 \% \text {, w/v), which was pre- } \\
\text { mixed with ethanol(as a co-surfactant), followed } \\
\text { by high speed homogenization process }\end{array}$ \\
\hline Chivero et al, 2016 & $\begin{array}{l}\text { Gum Arabic \& Xanthan Gum Assess- } \\
\text { ment of soy soluble polysaccharide, Gum } \\
\text { arabic and OSA-Starch as emulsifiers for } \\
\text { mayonnaise-like emulsions }\end{array}$ & $\begin{array}{l}\text { It was concluded that it is possible to employ hy- } \\
\text { drocolloid emulsifiers to produce mayonnaise. }\end{array}$ \\
\hline Dodi et al, 2016 & $\begin{array}{l}\text { guar Gum Carboxymethyl guar Gum } \\
\text { nanoparticles for drug delivery applica- } \\
\text { tions: Preparation and preliminary in- } \\
\text { vitro investigations }\end{array}$ & $\begin{array}{l}\text { Results obtained so far suggest that carboxymeth- } \\
\text { ylated guar Gum nanoparticles formulated with } \\
\text { STMP warrant further investigations as polysac- } \\
\text { charide based biocompatible drug nanocarriers. }\end{array}$ \\
\hline Mudgil et al, 2016 & $\begin{array}{l}\text { guar Gum Development of functional } \\
\text { yoghurt via soluble fiber fortification } \\
\text { utilizing enzymatically hydrolyzed } \\
\text { guar Gum }\end{array}$ & $\begin{array}{l}\text { Results revealed that partially hydrolyzed guar } \\
\text { Gum could be potentially used for soluble fiber en- } \\
\text { richment of yoghurt with acceptable functional and } \\
\text { sensory quality. }\end{array}$ \\
\hline $\begin{array}{l}\text { Jayabrata Maity, Samit Kumar } \\
\text { Ray, } 2016\end{array}$ & $\begin{array}{l}\text { guar Gum Enhanced adsorption } \\
\text { of } \mathrm{Cr}(\mathrm{VI}) \text { from water }\end{array}$ & $\begin{array}{l}\text { The structure of the hydrogels was characterized } \\
\text { and the hydrogels showing the best results in me- } \\
\text { chanical and swelling properties were used for the } \\
\text { removal of low (5-50 mg/L) and high }(100-800 \\
\mathrm{mg} / \mathrm{L}) \text { concentration of } \mathrm{Cr}(\mathrm{VI}) \text { ions from water. } \\
\text { The composite hydrogel showed a high removal of } \\
97.8 \%(4.89 \mathrm{mg} / \mathrm{g} \text { gel }) \text { and } 91.4 \%(182.4 \mathrm{mg} / \mathrm{g} \text { gel }) \\
\text { at an initial feed metal ion concentration of } 5 \mathrm{mg} / \mathrm{L} \\
\text { and } 200 \mathrm{mg} / \mathrm{L} \text {, respectively }\end{array}$ \\
\hline
\end{tabular}




\begin{tabular}{|l|l|l|}
\hline Chung et al., 2016 & $\begin{array}{l}\text { Gum Arabic Enhancement of colour } \\
\text { stability of anthocyanins in model bev- } \\
\text { erages }\end{array}$ & $\begin{array}{l}\text { this study provides valuable information about en- } \\
\text { hancing the stability of anthocyanins in beverage } \\
\text { systems using natural ingredients }\end{array}$ \\
\hline $\begin{array}{l}\text { Ranjbar-Mohammadi et al., } \\
2016\end{array}$ & $\begin{array}{l}\text { Tragacanth Gum nanofibrous scaffolds } \\
\text { for application in regeneration of pe- } \\
\text { ripheral nerve damage }\end{array}$ & $\begin{array}{l}\text { Results of 8 days of in vitro culture of PC12cells } \\
\text { on aligned PLLA/GT 75:25 nanofibers, showed } \\
20 \% \text { increase in cell proliferation compared to } \\
\text { PLLA/GT 75:25 random nanofibers. PLLA/GT } \\
75: 25 \text { aligned nanofibersacted as a favorable cue to } \\
\text { support neurite outgrowth and nerve cell elonga- } \\
\text { tion compared with PLLA nanofibers. Our results } \\
\text { showed that aligned PLLA/GT 75:25. }\end{array}$ \\
\hline Razavi et al., 2016 & $\begin{array}{l}\text { guar Gum, sage seed Gum Investiga- } \\
\text { tion of the interaction between sage } \\
\text { seed Gum and guar Gum }\end{array}$ & $\begin{array}{l}\text { With increasing SSG fraction, the extent of viscos- } \\
\text { ity reduction in the range of 0.01-316s-1 increased } \\
\text { from 58.68 for GG to 832.73 times for SSG which- } \\
\text { was not the same at different ranges of shear rate. }\end{array}$ \\
\hline
\end{tabular}

\section{Conclusion}

Diversity and functionality of Gums and regarding their still novelty in food industries have made Gums one of the main additives

\section{REFERENCES}

1 Chiveroa P., Gohtanib S., Yoshiib H., Nakamurac A. Assessment of soy soluble polysaccharide, Gum Arabic and OSA-Starch as emulsifiers for mayonnaise-like emulsions. LWT - Food Science and Technology, 2016, no. 69, pp. 59-66.

2 Chunga C., Rojanasasitharab T., Mutilangib W., Julian McClementsa D. Enhancement of colour stability of anthocyanin in model beverages by Gum Arabic addition. Food Chemistry, 2016, no. 201, pp. 14-22.

3 Dodia G. A., Palac E., Barbud D., Peptanariue D. et al. Carboxymethyl guar Gum nanoparticles for drug delivery applications: Preparation and preliminary in-vitroinvestigations. Materials Science and Engineering: C, 2016, no. 63, pp. 628-636.

4 Glicksman M. Functional properties of hydrocolloids, in Food Hydrocolloids Vol I, Boca Raton, FL, CRC Press Inc., 59, 614-hoefler ac, Practical Guides for Food Industry, Hydrocoloids, Eagan PressHandbook Series, 2004, pp. 33-34.

5 Hua Q., Gerharda H., Upadhyayab I., Venkitanarayananb K., et al. Antimicrobial eugenol Nano emulsion prepared by Gum Arabic and lecithin and evaluation of drying technologies. International Journal of Biological Macromolecules, 2016, no.87, pp. 130-140.

6 Maity J., Ray Samit K. Enhanced adsorption of $\mathrm{Cr}(\mathrm{VI})$ from water by guar Gum based Composite hydrogels. International Journal of Biological Macromolecules Available online 13 April In Press, Accepted Manuscript - Note to users, 2016.

\section{INFORMATION ABOUT AUTHORS}

Farnoush Hassanpour, food science and technology department, Isfahan (Khorasgan) branch, Islamic azad university, Isfahan, Iran CONTRIBUTION

Farnoush Hassanpourwrote the manuscript, correct it before filing in editing and is responsible for plagiarism

\section{CONFLICT OF INTEREST}

The author declare no conflict of interest. among them and combined matrixes produced by them also need to be studied in details.

7 Mudgila D, Baraka S., Khatkarb B.S. Develpment of functional yoghurt via soluble fiber fortification utilizing enzymatically hydrolyzed guar Gum. Food Bioscience, 2016, no. 14, pp. 28-33.

8 Pimenov N., Laishevtcev A., Pimenova V. The identification of salmonella infection in hatching eggs and products of turkey-keeping. Russian Journal of Agricultural and Socio-Economic Sciences, 2015, no. 10, pp. 9-17.

9 Pimenov N., Laishevtcev A., Lenev S., Semykin V. et al. Improvement of allocation and identification of salmonella enterica bacteria of arizonae subspecies. International Journal of Pharmaceutical Research \& Allied Sciences, 2016, no. 5(2), pp. 342-348

10 Pimenov N. Specific control of salmonella in poultry. Russian Journal of Agricultural and Socio-Economic Sciences, 2013, no. 11, pp. 16-23.

11 Phillips G., Williams P. Gum arabic, in Phillips GO and Williams PAHandbook of Hydrocolloids, Cambridge, Woodhead Publishing, 2000, no. 164, pp. 167.

12 Ranjbar-Mohammadia M. P., Prabhakaranb M., Bahramic S.H., Ramakrishnab S. Gum tragacanth/poly -lactic acid) nanofibrous scaffolds for application in regeneration of peripheral nerve damage. Carbohydrate Polymers, 2016, no. 140 , pp. 104-112.

13 Razavia S. M. A., Alghooneha A., Behrouziana F. W., Cuib S. Investigation of the interaction between sage seed Gum and Guar Gum: Steady and dynamic shear rheology. Food Hydrocolloids2016, no. 60, pp. 67-76.

\section{RECEIVED 10.22.2016}

ACCEPTED 11.27.2016 